\title{
The Gold Coast as a city of 'adolescent urbanism'.
}

\begin{abstract}
Australia's urban landscape is relatively young and our oldest cities are little more than two hundred years old. But some are much younger, emerging only recently and growing rapidly. In the space of little more than one generation the City of Gold Coast has become Australia's sixth largest city, having only come into existence as a local government entity in 1959. The pace and extent of this growth is seen by some as exemplary and as a model for other emergent Australian cities, and by others as the epitome of unregulated and unsustainable urban growth.

This paper analyses the nature, extent and pace of urban growth in the City of Gold Coast using a framework derived from theories of human development. It treats the city as a case of 'adolescent urbanism' in which rapid physical growth is accompanied by identity confusion, hubris \& egocentricity, entrepreneurial zeal and emergent forward thinking. The paper goes on to briefly consider possible future trajectories of the city, in particular its prospects for growing up and becoming a more mature city as well as the risks (or opportunities) associated with remaining an adolescent city. The paper concludes by reflecting critically on the potential for applying this developmental conception of urban growth in the City of Gold Coast to other Australian cities.
\end{abstract}

8830 words

6 November 2015

Revised draft

Paul Burton

Griffith University

Gold Coast 


\section{Introduction}

When we look at cities historically we can usually mark their emergence as urban centres and often their official designation as a city according to whatever administrative precedents and principles applied at the time. However, we do not and cannot know their longer term future, just as we cannot know with any degree of certainty the long term future of anything. Nevertheless, it is possible to take some of the concepts from 'stages of development' models applied to humans and consider whether they might help us to better understand the development trajectories of Australian cities.

There is a tradition in urban studies of analysing cities at various stages of their development and of looking at how cities experience the transition from one stage to another. Jane Jacobs 'Death and Life of Great American Cities' (1961) remains one of the best known books to take this kind of developmental approach, even if her methods and conclusions have since been comprehensively criticised (Page and Mennel, 2011). Galster's (2012) contemporary account of the demise of Detroit considers what might be the end a major American city, while closer to home Graeme Davison's (2004) 'The Rise and Fall of Marvellous Melbourne' charts a particular period in that city's history and in its latest edition offers some brief thoughts on how the city is still trying to recreate the conditions that made it so marvellous in the past.

Of course, compared to many of the great cities of Europe, Africa and Asia, Australian cities are a very recent phenomenon, only emerging after European settlement in the late $18^{\text {th }}$ century. One of the oldest surviving buildings in Australia, Old Government House in Parramatta, was completed around 1799. In comparison, therefore, with the long established cities from elsewhere in the world, all Australian cities could be described as being in their infancy. But this would be misleading as infancy is a relative concept and to compare the age of Australian cities with more ancient cities from elsewhere underplays the importance of analysing particular Australian cities in their Australian temporal context. 
The city chosen as the object of analysis in this paper is the Gold Coast in South East Queensland, now the sixth largest in Australia and under the jurisdiction of the second largest local government by population in the country. As a comparatively recent addition to the Australian urban landscape it has not yet acquired what Sudjic (1992) calls a 'picturesque crust' but it is nevertheless a place worthy of serious analysis for various reasons. It has grown rapidly and may well continue to do so in the future; its local government is not divided as in most other major and capital cities in Australia and throughout its administrative existence it has tried to manage a set of tensions between entrepreneurialism and regulation, between free market principles and planning, and between an image of fun and frivolity and one of maturity. Its experience in managing these tensions offers valuable lessons for Australia's other growing cities.

This paper takes a developmental perspective on the nature of contemporary Australian urbanism and urbanisation, drawing on work about the psychological development of humans and in particular on the period in which adolescents (attempt to) manage the transition to adulthood. The paper suggests that in the $21^{\text {st }}$ century the city of Gold Coast has attempted to manage a similar transition, from one displaying many of the equivalent aspects of adolescent urbanism to one showing some signs of greater maturity. It begins by considering briefly some of the key literature on the psychological characteristics of adolescence and the transition to adulthood, before examining each of the main features of this period and transition process in relation to the historical development of the city since its constitution as the City of Gold Coast in 1959. The paper concludes by reflecting on the extent to which the Gold Coast experience might also apply to rapidly growing Australian cities in the future. ${ }^{1}$

\footnotetext{
${ }^{1}$ The paper develops an argument first presented at the 2009 State of Australian Cities conference and I am grateful to all who offered critical comments at the time and on subsequent versions. I would especially like to acknowledge Tory Jones, Executive Coordinator Major Projects at City of Gold Coast who first introduced me to the notion of the Gold Coast as an adolescent city.
} 


\section{Adolescence and the transition to adulthood}

Until the turn of the $20^{\text {th }}$ century the transition from childhood to adulthood was relatively short (Erikson, 1968), although it may well have been just as traumatic a transition as that experienced by young people today. For the last one hundred years this period of transition has typically been extending over a longer period of time as many children become adolescents at a younger age and become adults at an older age. For example, while formal and juridical markers such as the age at which a young person can own property, assume legal responsibility for their actions and get married have remained relatively static in most western societies, many argue that the age at which young people become sexualised and begin to act as relatively autonomous consumers is dropping (Beder, Varney and Gosden, 2009)

Regardless of these extensions to the period of adolescence, it continues to be seen by developmental psychologists and behavioural analysts as a relatively troublesome period or state of being. It is associated typically with emotional turmoil, occasional displays of aggressive behaviour, anxiety, heightened risk taking, mood swings and significant and often rapid physical growth.

The academic study of adolescence emerged in the early years of the $20^{\text {th }}$ century with GS Hall's (1904) foundational work suggesting that certain forms of behaviour represented a re-enactment of stages in the general evolutionary development of humans. For example, what he described as the 'unruly behaviour of high school students' was taken to reflect a more general behavioural trait of earlier and more barbaric and savage epochs of human development. By the 1920s and 1930s Mead (1929) and Malinowski (1932) brought some of the emerging techniques and principles of ethnographic and anthropological research to bear on adolescent development and demonstrated the importance of cultural context in properly understanding the nature of adolescence and the processes affecting the transitions into and through it. In the second half of the century Piaget's work (eg Inhelder and Piaget, 1958) on the stages of cognitive development among children highlighted the growing capacity for abstract thought and analytical reasoning as a defining feature 
of his fourth and final stage of development: adolescence. Erikson (1968) also defined various stages of development and described adolescence as the fifth of eight stages, characterised as a period of identity formation in which children draw on their past experience in trying out and settling on an identity for their transition to adulthood.

Following Adams (2000) and drawing on all of these traditions and perspectives we can imagine a list of the key characteristics of adolescence that might be applied in the analysis of processes of urbanisation and forms of urbanism found in any particular place. These are:

- Rapid physical growth and significant transformations in size and shape;

- Identity exploration, including exploration and adoption of new identities and occasional crises of identity;

- Hubris and ego-centrism;

- Development of analytical capacity and thinking about the future;

- Risk taking.

Superficially, each of these characteristics appears to resonate with aspects of behaviours seen in the development and political management of the Gold Coast. But the city is not, of course, an individual adolescent person and we must be careful when treating it conceptually as such. Cities are places that contain many different people, with many different views, who behave in very different ways. Nevertheless, for analytical purposes we frequently treat cities as relatively coherent entities even if we still struggle to define exactly what we mean by a city (Amin and Thrift, 2002) and recognise that this represents the application of an ideal typical construct rather than reality itself. This paper takes a similar approach in using the characteristics set out above to analysis public opinion, policy positions and the behaviour of a wide range of 'city managers', including local government planners and politicians.

\section{Adolescent urbanism and the Gold Coast}


Each of these five key characteristics is discussed in turn below.

\subsection{Rapid growth}

In 1958 the Town of South Coast adopted a new name - the Town of Gold Coast - and one year later became the City of the Gold Coast. In 1949 the inland shires of Coomera and Beenleigh merged to form Albert Shire and in 1995 the City of Gold Coast and Albert Shire merged to form what is essentially the present day city. It has always been a city characterised by rapid population growth, with especially strong periods of growth in the periods 1967-74, 1982-89 and from 1990-2010. From 1961-2007 the city of Gold Coast grew by over $1630 \%$, compared to $199 \%$ for Brisbane and $99 \%$ for Sydney (KPMG, 2015a). Between 1990 and 2013 the population of the city doubled from approximately one quarter to half a million people. Since 1987 its net annual growth has ranged between 10,000 and 19,000 and it is projected to grow by around 15,000 people per annum over the next twenty years, reaching one million early in the 2050s. It is likely to retain its position as the sixth largest city in Australia, but it is possible that it will overtake Adelaide at some point in the next fifty years (KPMG, 2015a). In addition to these permanent residents, the city accommodates an average of 40,000 visitors each night of the year and over 11 million people visit the city each year, mainly as tourists.

To house this growing population of permanent residents and visitors, developers have been building houses, apartments and tourist accommodation at a prodigious rate for many years. While the global economic and financial crisis of 2007-08 saw a significant slowdown in new housing approvals and construction in the city (City of Gold Coast, 2015), Queensland in general and the Gold Coast in particular have been at the leading edge of the house construction boom for many years, notwithstanding rapid growth in some mining areas in other parts of Queensland and in Western Australia (UDIA, 20014).

The urban footprint of the Gold Coast has expanded over the decades but continues to reflect the city's origins in the distinction between its narrow coastal strip and more extensive hinterland. The 
former has always been the location of relatively high density residential suburbs, many providing tourist accommodation and second home opportunities, while the latter is typically a low density, detached suburban landscape catering for more permanent residents.

\section{Insert Coolangatta poster about here with caption:}

\section{Coolangatta land sale, 1914}

Over the last five decades the form of new housing has often been innovative in terms of design (high rise apartment towers, gated communities and canal estates for example) and tenure (strata and community title and timeshare for example). From the last decades of the $19^{\text {th }}$ century parcels of land in Southport and what became known as Surfers Paradise were subdivided for residential development but from the 1930s onwards new building land was created in the flood plains of the Nerang \& Coomera River by pumping sand from the riverbed and while there was initial and understandable reluctance to build on sand, by the 1950s this approach had become widespread. More recently the expansion of residential development in the hinterland areas has been at the expense of bushland and involved the widespread clearance of native (and sometimes introduced) vegetation and extensive earthworks to produce flat blocks of land on which to build new detached homes.

A more complex and sophisticated property market emerged in the 1970s on the back of favourable tax breaks for property investors, the abolition of death duties by the Queensland government in 1977 and growing confidence among individual investors in buying off-plan via 'innovative' financing schemes offered by local developers (Burchill, 2005; McRobbie, 1984). At the peak of the 1980s property boom on the Coast, almost 2500 high rise units were sold and over 3500 under construction (Jones, 1986). One year later a major crash occurred with property sales dropping to virtually zero in 1984 and prices for high rise dwellings falling by 50-60\% (Jones, 1986). At the end of the 1980s a further crash hit the city when Japanese development finance all but disappeared following the collapse of its bubble economy (Hajdu, 2005). This reinforced the image of the city as 
place of considerable volatility within the property sector, but did little to halt the long term trend in the pace of population growth.

\section{Insert picture 4 about here}

While the speculative market for high rise buildings on the Gold Coast went through these periodic boom and bust cycles, in the suburbs growth was less spectacular but more steady. In the northwest the new suburbs of Pacific Pines and Coomera expanded quickly throughout the 1990s, while in the central area of the city, Singaporean developer Robin Loh embraced the principles of masterplanning in his development of 4,000 acres of land into the relatively self-contained township of Robina, helped by favourable treatment from the State government (Burchill, 2005).

The major challenges facing city leaders in the $21^{\text {st }}$ century are how to cope with the continued population growth projected for the city without compromising what are seen as the iconic environmental assets of the city and how to pay for the provision of infrastructure needed to support this growth. While higher urban densities and the selection of a limited number of regional growth centres has been the way forward preferred by successive Queensland governments and by the city council, representatives of the development industry portray the Gold Coast as a city constrained by an unduly tight urban footprint or growth boundary and suffering from over-inflated house prices as a consequence (UDIA, 2014). As a result there is constant political pressure to review and extend the urban footprint and to make more greenfield land available for residential development, while at the same time promoting higher density development in certain areas such as the Gold Coast Light Rail corridor.

\section{Insert map 1 about here}

The city has grown rapidly since its establishment largely because of the desire of inter-state and international migrants to move to it for a variety of reasons, including its climate, lifestyle and relatively cheap housing. While the climate is likely to remain favourable in comparison with many other places and the lifestyle is principally a marketing construct, housing in the city has lost 
something of its comparative advantage over equivalent properties on the fringes of Melbourne and Sydney. Furthermore, the availability of jobs and business opportunities is of increasing importance to prospective in-migrants and here the city is struggling to regain its competitive advantage. The transition from a local economy based on tourism, retail and construction - which employed approximately $40 \%$ of the workforce in 2012/13 (KPMG, 2015a) - to one offering a wider range of opportunities has long been a cornerstone of the city council's economic development strategy (City of Gold Coast, 2013). Achieving this will not easy, especially as economic diversification through inward investment and endogenous growth form the cornerstone of the economic development strategies of most major cities in Australia. Nevertheless, the city appears to be well-placed to capitalise on its particular combination of locational advantages (KPMG, 2015b)

It is possible that in the next fifty years the population of the city will grow but not at the same pace as it has in the past. Salt (KPMG, 2015b) describes this as a 'normalisation' of the growth rate to one that is similar to most other Australian capital cities and if correct we are likely to see a rather different set of political challenges facing the planners and leaders of the city; challenges based more on stimulating than on accommodating growth and which pay more attention to the changing composition of the population than to its mere size and rate of growth. Thus while the growing pains of the last fifty years may diminish, they are likely to be superseded by a new set of concerns related more to the changing age profile of the population and the need to adapt the built form rather than simply expand the urban footprint of the city. But it is also possible that the current increase in demand for property in the city and the renewed willingness to invest in major new developments from China and other East Asian countries will see some new growing pains emerge (Cranston, 2015; Juwai, 2013).

\subsection{Identity confusion}


In 1917 land in the town of Elston was offered for sale at auction as the Surfers Paradise Estate, an early illustration of a growing movement to transform the identity of the area in order to sell it. The adoption of the soubriquet 'Gold Coast' by Brisbane-based developers and real estate interests in the 1940s saw the separate towns of Southport, Nerang, Burleigh, Coolangatta and Mudgeeraba beginning to merge in the popular imagination into a new place. The outcome of this imaginative transformation and indeed its intention was to promote the Gold Coast as a place not only for local tourists from Brisbane and occasional visitors from inter-state, but increasingly as a place to move to permanently to make a new life (Griffin, 1998).

This transformation of the city from a collection of tranquil holiday villages to a 'sunny place for shady people' (Jones, 1986) continues to animate local debate about the future of the Gold Coast. Whether it should strive to retain remnants of its tranquil past, sometimes referred to as the city's 'relaxed lifestyle', or continue to trade on its louche and risqué reputation or adopt a more modern and sophisticated image as an international or global city; all remain points of contention in contemporary debates about the future of the city. Of course these debates are not peculiar to the Gold Coast and indeed the epithet 'a sunny place for shady people' was first used by W Somerset Maugham (1941) to describe Monaco in the inter-war years and has been appropriated by any number of resort cities since then, including Tampa, Miami, Acapulco and Las Vegas.

Recently the city attempted to develop a more sophisticated and mature identity, emphasising its growing cultural base and the significance of its 'knowledge industries' clustered around its main universities and an expanding health-related R\&D sector. Through its Bold Future strategic visioning exercise the City Council made a concerted effort to emphasise the 'green, gold and blue' of the city epitomised by its hinterland forests, beaches and waterways and the sea but in particular its 'green' credentials. The vision for the city proposed by the Bold Future process and endorsed by the council stated, 
Defined by our spectacular beaches, hinterland ranges, forests and waterways, the Gold Coast is an outstanding city which celebrates nature and connects distinct communities with the common goal of sustainability, choice and well-being for all. (Bold Future Advisory Committee, 2008)

This aspirational vision of a comparatively 'green' future is in stark contrast to the dystopian vision offered by Brisbane Courier Mail journalist and novelist Matthew Condon who described the 'sinister underbelly' of Surfers Paradise in a piece headed:

Malice in Wonderland - They used to call it paradise. That was before the guns, gangs and hoons cast their shadow over Surfers. (Condon, 2008)

In this he spoke with young people watching an early evening street fight who told him, "This is what we come out for." The epitome of this volatile mixture of young people, alcohol and occasional violence is the annual Schoolies festival when around 30,000 school leavers visit the Gold Coast over the course of three weeks in December and where, according to Winchester et al (1999) they may learn to balance celebration and control in an important rite of passage.

\section{Insert picture 3 about here}

While some bemoan the anti-social behaviour of young people at Schoolies, only a few weeks before this in the Gold Coast social calendar, some adults get a similar opportunity to behave badly at the annual street car race through the city. Since 1991 this three day event has attracted over 300,000 visitors to watch IndyCars and most recently V8 supercars race through the streets of Surfers Paradise. But in addition to the car racing this long weekend has also become renowned for trackside balcony parties, excessive alcohol consumption and lewd behaviour. Some years ago, according to newspaper reports, the then Queensland Premier took offence at some of this bad behaviour, 
A sleaze crackdown at this year's Gold Coast Indy has been ordered by Premier Anna Bligh, who warned revellers they will face arrest if they "cross the line". Ms Bligh was offended by "lewd" behaviour, including women flashing their breasts on high-rise balconies, during her first visit to Indy as Premier last year and has told organisers to clean up their act. (Stolz, 2008)

In many respects both Schoolies and street car racing highlight one of the major challenges facing the city's image makers: do they continue to promote (and subsidise) major events that attract visitors and allow many local enterprises to make money irrespective of their impact on the reputation of the city as a place 'famous for fun' or do they try to extend the repertoire of cultural and sporting events to include those that are more 'respectable'? The combination of political arguments about respectability with more rational assessments of value for money does not make it any easier to meet these city image making challenges.

The reality of day-to-day life for most Gold Coast residents is of course rather different: neither another day in paradise nor a walk on the wild side. But we are concerned here with the public identity of the place as a whole and in particular with how the city leaders have attempted to promote a particular identity. In this respect there has been a tendency in recent years to play down the free-wheeling developer identity of earlier times captured best by the image of the 'white shoe brigade $^{2}$ and to move on from its identity as a playground both for the rich and famous (staying at the upmarket Palazzo Versace) and for the ordinary working families or 'battlers' (staying at the more modest Ashmore Palms Holiday Village) ${ }^{3}$. There have been concerted efforts to project an image of 'greenness', especially of late to Chinese tourists and of modernity via the promotional material of the Council's Economic Development and Major Projects Directorate, which has

\footnotetext{
${ }^{2}$ The White Shoe Brigade refers to a group of property developers and entrepreneurs working mainly in South East Queensland from the 1970s onwards whose plans were often supported by State and local government politicians in the face local concerns over their environmental and social impacts. See Forbes and Spearritt, 2003.

${ }^{3}$ Battlers is an Australian colloquial phrase used typically to describe working class individuals and families struggling valiantly in the face of low wages, high rents and mortgages. See Sekiya, 2008.
} 
published brochures entitled 'Gold Coast Innovation City' and 'Competitive Gold Coast City' (Burton, 2016).

The election of Mayor Tom Tate in 2012 saw a return to a city image focussed on entrepreneurialism and being 'open for business', although one more concerned with building a new economic base around health services and university-related R\&D than simply on free-wheeling property development. Nevertheless, new tourism developments remain important and substantial effort has been put into supporting the development of a new integrated resort and casino facility within the ecologically fragile Broadwater, a semi-enclosed estuary in the northern half of the city. Designed to appeal, inter alia, to so-called 'Chinese high rollers' this major project represents the latest attempt to balance the contrasting images of the city as a place for touristic fun and a place for investment in the new knowledge economy summed up in the desire to be seen (again) as a 'smart city'. It remains to be seen whether these new and more mature identities take hold and eventually displace the more city's adolescent personae of beach front debauchery and dubious developments built by members of the white shoe brigade (Burton, 2014).

\subsection{Hubris and ego-centricity}

Adolescence is often a time of great introspection punctuated by periods of extroversion and egocentrism. Adolescents can be preoccupied with themselves and find it difficult seeing things from the perspective of others. They can also resort easily to hyperbole when describing themselves and their plans for the future.

Many places display a high degree of hyperbole in their promotional material (Gold \& Ward, 1994) and hubris is never far below the surface of much that is written about the Gold Coast, especially by its boosters and promoters. Beyond the evocative name changes of the first half of the $20^{\text {th }}$ century 
when Shark Bay became Main Beach, Maclntosh Island became Paradise Waters and Goat Island became Chevron Island, great claims have always been made about Gold Coast.

\section{Insert pictures $1 \& 2$ about here}

The City Council captured this tone in its 2007-08 annual report describing the city as,

Naturally the world's best place to be... a city that is recognised internationally for the quality, diversity and sustainability of its lifestyle, economy and environment. The Gold Coast's future will be secure as Australia's most desirable place to live and favourite place to visit. (Gold Coast City Council, 2008)

Similarly the Chairman of the Bold Future Advisory Committee prefaced its report to Council by saying,

We are lucky to live in one of the best places on earth. Visitors have described it as living in paradise between the mountains and the sea (Bold Future, 2008)

while the city's inward investment agency, Business Gold Coast now claims,

The Gold Coast is a city coming of age. It is a place of opportunity that, over the next decade, will transform into a globally-recognised city while retaining its enviable lifestyle and stunning natural environment. (City of Gold Coast, 2014)

From further afield, the Intelligent Communities Forum (2015), an international think tank promoting IT connectivity in social and economic development included the Gold Coast in its listing of Smart21 Communities from 2008-10, prompting local claims that the city was now recognised as '..a more intelligent society than people give it credit for.' (Skene, 2015)

This hubris and hyperbolic tendency is not the same as egocentrism, but there are signs of this as well. While promoting itself as a destination for national and international tourism and as a major conference city, the City Council is rather more ambivalent about its capacity to learn from elsewhere or to encourage senior officers or councillors to travel abroad to experience at first-hand 
how similar local governments manage the problems they face at home. In the face of a concerted campaign in the local press to define any trips inter-state or abroad as 'junkets', the Council wavered over its policy on supporting promotional or study trips (Chambers, 2009a). Local Federal MP, Steve Ciobo argued that while federal members clearly need to travel overseas as part of their job, local councillors should stay at home and 'deal with grassroots issues'. The Mayor at the time, Ron Clarke (2004-12), was reported as saying that 'he would prefer to stay on the Gold Coast to represent the needs of local residents' (Chambers, 2009b) rather than attending the second meeting of the Australian Council of Local Government in Canberra. In short the city at that time was happy to proclaim itself as one of the best places to live in Australia and to encourage others to visit and move here, but unwilling to allow its civic leaders to venture aboard too often, or even to Canberra! The current mayor has adopted a more outward looking stance and regularly leads trade and investment delegations to China and to the Middle East, although conscious of accusations of ratepayer-funded junkets, he typically pays his own travel costs. While this does indeed provide a degree of political insulation from media accusations of unnecessary extravagance, it also undermines the legitimacy of such trips as proper council business.

While claiming or aspiring to be the world's best is certainly not confined to cities (universities for example are increasingly prone to make similar claims), the extent to which these claims are supported by any empirical evidence typically lags behind and should also be seen alongside the similar claims made by virtually every other city.

Just as adolescents tend to oscillate between periods of self-doubt or status anxiety and periods of extreme self-confidence, so cities such as the Gold Coast can veer quickly from seeing themselves as self-evidently among the best places on earth to live or to invest to being wracked with concern about their attractiveness to migrants or to investors. While more mature cities might recognise that lower than normal growth rates are likely to return to normal at some point and that the failure to attract particular footloose industries does not spell the end of economic development strategy of 
diversification, the adolescent city is more likely to experience these urban policy setbacks as traumatic rejections that cannot be overcome. The Gold Coast is beginning to accept that economic success does not have to rely on attracting major firms such as Google or Microsoft, but can be achieved through attracting less high profile but nonetheless significant employers and by helping local firms grow (KPMG, 2015a)

\subsection{Forward thinking and planning for the future}

The reputation of the Gold Coast as a place of unbridled capitalism with a deep seated entrepreneurial spirit in which a combination of luck and optimism prevailed took hold in the boom period of the 1950s and continued, despite the bust periods of the 1970 s and 80 s, through to the early 1990s. Throughout the 1970s and 1980s, Premier Joh Bjelke-Peterson presided over a regime in Queensland characterised at times by corruption and political abuse, but also one which saw substantial investment in infrastructure and an especially permissive approach to planning (Fitzgerald, Megaritty and Symons, 2009; England, 2010). In this period the city was widely held to have succeeded because of the absence of local government or state planning, even if the successful entrepreneurs had their own visions of the future and plans for how to achieve them (McRobbie, 1984). Although a Gold Coast Strategic Plan was adopted in 1969, it provided little check on the ambitions of local developers and as Doug Jennings, the National Party member of the state parliament for Southport said in 1982, '...because of the wide discretionary powers contained in the town plan for the Gold Coast, the City Council can change anything overnight. It is not a town plan, it is simply a convenience document' (Jones, 1986: 62). Jones goes on to claim,

The Gold Coast has been developed without modern town planning methods; this may be the key to its success and vitality...The virtual absence of town planning enables the Gold 
Coast real estate economy to respond to sudden changes in demand and so develop and crash remarkably quickly..(Jones, 1986:62)

But as critiques of planning from Marxist and other critical perspectives assert (eg Friedman, 1971; Dear \& Scott, 1981), planning by the local state in capitalist societies performs an essential role in regulating the excesses of the market; providing a degree of certainty and predictability that is conducive to maintaining profitability and managing the externalities of unfettered development. It is not surprising, therefore, that even in a supposedly 'free market city' like the Gold Coast the demand for some planning and regulation grew, not just from local residents concerned with bad neighbour developments, but from the development sector itself. From the 1990s a more assertive and proactive city council began to produce and implement planning schemes that were increasingly comprehensive in scope and bold in their ambitions to regulate development in pursuit of a broader notion of a better city. It also began to take a longer term view, both in substance and procedure, of the future. For example, in its early years planning in the city tended to be concerned principally with providing a suitable canvas on which developers could pursue their dreams. More recently, however, the city's plans have become more concerned with the nature of these dreams and whether they are consistent with professional planning views and popular opinion of what constitutes a good city. The early years of the $21^{\text {st }}$ century saw the city of Gold Coast hoping to become known as much for the quality of its architecture and urban design (Leach, Rickard and Jones, 2015) as for its 'innovative' approaches to development financing and real estate marketing. In 2006 the City Council agreed to consider seriously and systematically the long term future of the city, including its economic, social and environmental sustainability and in June 2007 launched the Bold Future initiative, a strategic visioning project. An Advisory Committee (on which I served) was appointed to oversee the production of a long term vision, a set of strategic action statements and a complementary set of performance indicators. The Advisory Committee met over the following year to consider a set of analytical reports synthesising research and best practice on a range of issues, as well as the results of an extensive programme of public consultation and community engagement. It 
submitted its report to the City Council at the end of 2008 and this was endorsed in January 2009. It was then used as the foundation of a number of more focused statutory plans, including the Council's Corporate and Operational Plans, the Gold Coast Planning Scheme of 2011 and a Community Engagement Strategy that operationalised the Bold Future commitment to openness and transparency in decision making. The election of a new Council and Mayor in 2012 saw a new strategic direction adopted and the gradual replacement of some but not all of the Bold Future principles and priorities. This process of community-based, long term and strategic planning had proved challenging for many who had grown used to a more informal, reactive and instinctive approach to planning for the city's future, not least because it had often done little to fetter their development ambitions.

However, in 2014 the city council and others (including major local businesses, Griffith University and Regional Development Australia, Gold Coast) commissioned a major study of long term trends and urban possibilities for the city from KPMG (2015b), attempting to anticipate what might occur 'beyond the horizon' and planning accordingly. The report charts a number of possibilities for the growth of the city and provides an interesting mix of demographic and economic forecasting and civic boosterism (Boyle, 1997) and while many of its future possibilities had been foreshadowed in existing documents, it demonstrates the renewed commitment by the council and other agencies to ensure the city remains a place noted for its entrepreneurial spirit.

Thus, for many of its early decades the city appeared to follow former Queensland Premier BjelkePetersen's laissez faire attitude epitomised in his infamous catchphrases, 'she'll be right' and 'don't you worry about that' (Lunn, 1987). However this disposition seems finally to have to be overtaken by a more forward looking and analytical approach to thinking about the future of the city. Just as many adolescents struggle to appreciate the benefits of long term financial and career planning and tend to take a more opportunistic approach, so the city took some time to reach this conclusion and to start planning seriously and systematically for its long term future. 


\subsection{Risk taking, innovation and entrepreneurialism}

It is sometimes observed that two new major cities emerged in Australia in the $20^{\text {th }}$ century, Canberra and the Gold Coast, with the former representing the epitome of a planned city and the latter a product of entrepreneurialism, risk taking and innovation. While these stereotypical representations may well be exaggerations, they capture something of the reality of the development trajectory of each place. And while local and state governments have always played a supportive role in providing infrastructure, social and community services and the occasional legislative boost to some major development projects in the city of Gold Coast such as Robina and Sanctuary Cove, the popular perception remains that it was built by a handful of 'great men'; risk takers and innovators who saw the potential for transforming what was mainly a flood prone area of mangrove swamp and unstable foreshore into one of Australia's leading cities and one of its most successful examples of 'touristic urbanisation' (Mullins, 1990). The Gold Coast is not alone in this and accounts of major urban transformations include the importance of Baron Haussmann acting in the service of Napoleon III to transform Paris in the second half of the $19^{\text {th }}$ century (Pinkney, 1955), of the regeneration of Barcelona by a combination of strong mayors such as Joan Clos and Pasquall Maragall with innovative architects such as Oriol Bohigas (Blanco, 2009), and the role of Mayor Rudi Giuliani in 'cleaning up' New York (Weikart, 2001). But the 'great men' of the Gold Coast have been property developers rather than architects, planners or politicians. Jim Cavill, Sir Bruce Small, Jock Macillwain, Jim Raptis and Sohail Abedian are responsible for many of the most prominent buildings and residential estates in the city and this remains important in a place that defines itself so much in terms of its buildings and built form. ${ }^{4}$

\footnotetext{
${ }^{4} \mathrm{Jim}$ Cavill settled in what was then known as Elston and succeeded, in 1933, in having it renamed 'Surfers Paradise', conveniently reflecting the name of his highly successful Surfers Paradise Hotel. Sir Bruce Small moved to the city in the 1950s and became a successful property developer, before being elected as Mayor of the city in 1967 with the slogan, 'Think big, vote Small'. He introduced a more robust planning scheme but also promoted the city's attractions, including by using the famous Gold Coast Meter Maids.
} 
But there are fewer prominent and successful entrepreneurs working in other sectors of the local economy, although there have of course been many successful business people who have made (and sometimes lost) their fortunes in the city. The city does not have a central business district as it is understood in most cities, even though the historic neighbourhood of Southport was recently designated 'the CBD of the Gold Coast' and given Priority Development Area status by the state government in 2014. While it may well grow into this role in the future, at present it has no significant collection of large commercial businesses or any concentration of business services such as lawyers, accountants and financiers. Indeed the city has no especially large firms located within its borders and the dominant employers are the city council, hospitals and the universities. Rather the city is widely regarded as the franchise capital of Australia and most of its entrepreneurial spirit is associated with small, family-run businesses in food retailing and personal services.

Some of these small scale enterprises will no doubt grow into medium sized and larger firms, but there is criticism (by no means uncommon) from small business associations such as local chambers of commerce that the regulatory environment within the city, including via its planning scheme, is by no means helpful to small businesses trying to establish themselves and to grow. While this is perhaps not an uncommon criticism in the Gold Coast or elsewhere, the city has not yet regained its reputation as a place where its entrepreneurial spirit is leading to significant new business growth.

Although the city is sometimes portrayed as something of cultural desert (Wise, 2006) it is actually in this sector of the economy that young entrepreneurs are building a reputation for the city as a place of innovation and creativity, including in the film industry (three quarters of Queensland film

Jock Mclllwain worked originally as an engineer before becoming a successful property developer in the city, and then a city councillor. He is now renowned for his philanthropy and support for the arts and education and was awarded an Honorary Doctorate by Griffith University in 2013.

Jim Raptis moved to the Gold Coast in the 1970s and developed a number of architecturally distinctive holiday apartment projects. His Raptis Group has twice collapsed financially, but has recently been approved to trade again on the Australian Stock Exchange. He remains the Honorary Consulate General of Greece in Brisbane. Sohail Abedian founded the Sunland Group in 1983 and has been responsible for some of the most iconic buildings in the city, including Q1, claimed to be the tallest residential tower in the southern hemisphere and Pallazo Versace, the first Versace-branded hotel. He recently sponsored the Abedian School of Architecture at Bond University, designed by Sir Peter Cook and CRAB studio. 
production takes place in the city) and in health technology development associated with Griffith University. It may well be that adolescent enthusiasm and risk taking in the so-called creative industries will help transform the reputation of the city and enable its transformation into a more mature place in the future.

\section{Particularity and generalisability}

This paper has approached the task of trying to understand the nature of Gold Coast urbanism by employing the notion of adolescence as an analogical analytical device. At the outset this appeared to offer some promise simply because the Gold Coast is such a young city by European standards, is growing quickly and appears to be experiencing growing pains similar to those suffered by many adolescents.

However, there are also flaws in the heuristic value of adolescence as an analytical device for understanding processes of urban change. One of the most obvious is the absence of a parental equivalent. Children are born of parents and even if their parents are absent when they become adolescents, in most cases someone else takes on the role - in loco parentis. In human development a major aspect of adolescence is conflict with parents and other authority figures. Parents and others typically impose the restrictions that frustrate adolescents and often prompt further episodes of challenging behaviour. Adolescents choose to accept or more often to reject the preferences and values of parental figures in searching for their own distinctive identity, even if they eventually embrace them at a later date.

But cities do not have parents in this sense, even though we may talk of 'city fathers', although rarely if ever of 'city mothers'. While other state or federal agencies may encourage the expansion of towns and anticipate their transition to places with city status, there is a greater degree of selfdetermination in the formation of cities, at least in an Australian context. This is not to suggest that 
political conflict between the tiers of government and especially between city and state governments is not serious and profound, but the relationship is not so clearly analogous with that of a parent and child. In other words it would be stretching the analytical analogy too far to place jurisdictionally superior bodies such as state or federal governments in the role of parents, even if city governments usually owe their constitutional existence to these bodies.

Insofar as adolescence is a phase that virtually everyone passes through and even though we may sometimes speak of perpetual teenagers suffering from arrested development, the majority make the transition to adulthood without too much difficulty. While parents are often concerned that patterns of behaviour in adolescence will play an important part in the future development of their children, in retrospect adolescent traumas are not always as significant as they might have seemed at the time. This may well also apply to young and rapidly growing cities. At times they may appear to be on a self-destructive path: growing too quickly, making exaggerated claims about their abilities, engaging in risky economic behaviour and mixing with the wrong kind of people. But if we look at the history of most mature cities we will see similar stages of development that in retrospect did little to affect their urban trajectory or stunt their growth as they grew into maturity.

But if there is some merit in understanding the Gold Coast as a particular form of adolescent urbanism, can we go further and conclude that this can be found in other cities at similar stages of development? This would require further systematic research, but there are cities in North and Central America and in some European Mediterranean countries that have grown rapidly on the back of tourism and are now looking to strengthen and diversify their economic base, to take a more conservative attitude to their environmental assets and to develop a more mature cultural identity. And the number of Chinese cities growing at an even more rapid pace surely provides fertile ground for urban researchers interesting in understanding the extent to which rapid growth can be planned and managed successfully. 
Australian cities have not and most likely will not experience growth of the scale or pace seen in China, but if the total population of Australia grows as anticipated in federal government intergenerational reports (Commonwealth of Australia, 2015) then the distribution of that enlarged population will become significant. Without a plausible national urban policy (Burton \& Dodson, 2014) it is most likely that much of this population growth will be concentrated initially in Sydney and Melbourne. But as housing and congestion costs continue to rise in these cities it is also likely that some of these new migrants to Australia will consider moving to other smaller cities and that these will experience some of the growing pains felt in the Gold Coast over the last fifty years. In this case, what has been a relatively limited experience of adolescent urbanism in Australia may well become more commonplace as some of the lessons learned by the city take on a wider relevance. 


\section{References}

Adams, G.R. (2000) Adolescent Development: The Essential Readings, New York: Wiley-Blackwell Amin, A. and Thrift, N. (2002) Cities: Reimagining the Urban, Cambridge: Polity Press

Beder, S., Varney, W. \& Gosden, R. (2009) This Little Kiddy Went to Market: The Corporate Capture of Childhood, Sydney: UNSW Press

Blanco, I. (2009) Does a 'Barcelona Model' really exist?, Local Government Studies, 35(3), 355-369

Bold Future Advisory Committee (2008) Our Vision for the Future of the Gold Coast, Report presented to the Mayor, 17 December 2008, Gold Coast: Gold Coast City Council

Boyle, M. (1997) Civic boosterism in the politics of local economic development - institutional positions and strategic orientations in the consumption of hallmark events, Environment and Planning A, vol 29, no 11, 1975-97

Burchill, G (2005) Passion, Power and Prejudice: a remarkable untold account of a magic city in the making, Gold Coast: Golden 12 Pty Ltd

Burton, P and Dodson, J. (2014) Australian Cities: in pursuit of a national urban policy in L Orchard and C Miller (eds) Australian Public Policy: Progressive Ideas in the Neo-Liberal Ascendancy, Bristol: The Policy Press, 245-261

Burton, P. (2014) From white shoes to bold futures: the neoliberalisation of local government in an Australian city?, Urban Studies, 51(15), 3233-3249, DOI: 10.1177/0042098014540944

Burton, P. (2016) The changing face of local government on the Gold Coast, in Bosman, C., Dedekorkut-Howes, A. and Leach A. (eds) Off the plan: the urbanisation of the Gold Coast, pp 109120, Melbourne: CSIRO Publishing

Chambers, G. (2009a) Pforr up in air for marine trip. Crichlow labels junket 'a joke'. Gold Coast Bulletin, 25 June, $\mathrm{p} 19$

Chambers, G. (2009b) Ron snubs Canberra, 'I went last year. There was a lot of discussion but very little action' Gold Coast Bulletin, 12 June, p7

City of Gold Coast (2013) Economic Development Strategy 2013-2023 (version 2.0), Surfers Paradise: City of Gold Coast

City of Gold Coast (2014) Gold Coast (inward investment booklet) available at: http://www.moregoldcoast.com.au/wp-content/uploads/2014/08/Australia_Gold-Coast_SalesBook_07_10_2014-low-res.pdf

City of Gold Coast (2015) Gold Coast Community Profile: Residential Building Approvals, accessed online 31/10/15 at:

http://profile.id.com.au/gold-coast/building-approvals

Condon, M (2008) 'Golden Rough' Courier Mail QWeekend, 7-8 June, pp12-19

Cranston, M. (2015) Asian buyers fuel Gold Coast property surge, Australian Financial Review, 24 June. Accessed on 29/10/2015 at:

http://www.afr.com/real-estate/asian-buyers-fuel-gold-coast-property-surge-20150609-ghkbu6 
Davison, G. (2004) The Rise and Fall of Marvellous Melbourne, $2^{\text {nd }}$ Edition, Melbourne: Melbourne University Press

Dear, M \& Scott A (1981) (eds) Urbanization and Urban Planning in Capitalist Society, London: Methuen

England, P. (2010) From revolution to evolution: two decades of planning in Queensland, Environmental \& Planning Law Journal, vol 27, no1, 53-68

Erikson, E.H. (1968) Identity: Youth and Crisis, New York: Norton

Fitzgerald, R., Megaritty, L. and Symons, D. (2009) Made in Queensland: A New History, Brisbane: University of Queensland Press

Forbes, J. and Spearritt, P. (2003) Rum Corps to White-Shoe Brigade, Griffith Review, no2, 23-35 Friedman, J. (1971) The future of comprehensive urban planning: a critique, Public Administration Review, 31(3), 315-326

Galster, G. (2012) Driving Detroit: The Quest for Respect in the Motor City, Philadelphia: University of Pennsylvania Press

Gold Coast City Council (2008) A Year of Change: 2007-08 Annual Report, Gold Coast: GCCC

Gold JR \& Ward SV (1994) (eds) Place Promotion: The Use of Publicity and Marketing to Sell towns and Regions, Chichester, John Wiley

Griffin, G. (1998) 'The Good, the Bad and the Peculiar: cultures and policies of urban planning and development on the Gold Coast', Urban Policy and Research, vol 16, no 4, 285-292

Hajdu, J. (2005) Samurai in the Surf: The arrival of the Japanese on the Gold Coast in the 1980s, Canberra: Pandanus Books

Hall, G.S. (1904) Adolescence: Its Psychology and Its Relations to Physiology, Anthropology, Sociology, Sex, Crime, Religion, and Education, 2 vols. New York: Appleton.

Inhelder, B. \& Piaget, J. (1958) The Growth of Logical Thinking from Childhood to Adolescence, New York: Basic Books

Intelligent Community Forum (2015) The Smart21 Communities, accessed (4/11/15) at: http://www.intelligentcommunity.org/

Jacobs, J. (1961) The Death and Life of Great American Cities, New York: Vintage Books

Jones, M (1986) A Sunny Place for Shady People, Sydney: Allen and Unwin

Juwai (2013) Top destinations for Chinese property buyers, Briefing Note, Shanghai: Juwai. Accessed on 29/10/2015 at:

https://list.juwai.com/bundles/juwailist/pdf/Juwai-map-FINAL.pdf

KPMG (2015a) Beyond the Horizon report to RDA Gold Coast, Melbourne: KPMG Demographics KPMG (2015b) Beyond the Horizon, Gold Coast: Regional Development Australia Gold Coast Inc Leach, A., Rickard, K. and Jones, F. (2015) GC30+ Documenting the Gold Coast Architecture Awards, 1984-2013, Gold Coast: Urban Research Program 
Lunn, H. (1987) Joh: The Life and Political Adventures of Sir Johannes Bjelke-Petersen, Brisbane: University of Queensland Press

Malinowski, B. (1932/2001) 'The Sexual Lives of Savages in North Western Melanesia' in Malinowski Collected Works, London: Routledge

McRobbie, A. (1984) The fabulous Gold Coast, Surfers Paradise: Pan News Pty. Ltd

Mead, M. (1929) Coming of Age in Samoa: A Psychological study of primitive youth for Western civilisation, New York: William Morrow \& Co

Mullins, P. (1990) Tourist cities as new cities: Australia's Gold Coast and Sunshine Coast, Australian Planner, 28 (3), 37-41

Page, M. and Mennel, T. (eds) (2011) Reconsidering Jane Jacobs, Chicago: American Planning Association

Pinkney, D.H. (1955) Napoleon III's transformation of Paris: the origins and development of the idea, Journal of Modern History, 37(2), 125-136

Sekiya, N (2008) Aussie 'battler' as a cultural keyword in Australian English, Griffith Working Papers in Pragmatics and Intercultural Communication 1, 21-32, accessed on 1/11/15 at:

www.griffith.edu.au/_data/assets/pdf_file/0003/72903/Issue1-noriko-sekiya-battler-in-ause.pdf

Skene, K. (2015) 'Think Tank: Rob Borbidge' Gold Coast Bulletin, 3 August, online edition, accessed (10/11/15) at: http://www.goldcoastbulletin.com.au/news/opinion/think-tank-rob-borbidge/storyfnj94itc-1227467559264

Somerset Maugham, W. (1941) Strictly Personal, London: William Heinemann

State of Queensland Department of Infrastructure \& Planning (2009) South East Queensland Regional Plan 2009-2031, Brisbane: DIP

Stolz, G. (2008) Highrise sleaze hits skids, The Courier-Mail (Brisbane), 15 August, p5

Sudjic, D (1992) The 100 Mile City, New York: Harcourt Brace Jovanovich

Urban Development Institute of Australia (2014) UDIA Submission re Draft City Plan, 29/7/14, Brisbane: UDIA (Queensland)

Weikart, L.A. (2001) The Giuliani Administration and the New Public Management in New York City, Urban Affairs Quarterly, 36(3), 359-381

Winchester, H., McGuirk, P. and Everett, K. (1999) Schoolies week as a rite of passage: a case study of celebration and control, in Teather, E.K. (ed) Embodied Geographies: Spaces, Bodies and Rites of Passage, London: Routledge, pp. 59-77

Wise, P. (2006) Australia's Gold Coast: a city producing itself, Urban Space and Cityscapes:

Perspectives from Modern and Contemporary Culture, Lindner, C. (ed.), Routledge, London, 177-291. 